\title{
ORIGINAL COMMUNICATIONS.
}

\author{
On Pragiogramma, a new Genus of Diatomacede. \\ By R. K. Greville, LL.D., F.R.S.E., \&c.
}

The only known species of the new genus of Diatomaceæ, which I propose to establish in this communication, was published by my late friend, Professor Gregory, in 1857, in his paper "On the Marine Diatomaceæ of the Clyde" ("Trans. Roy. Soc. Ed.,' vol. xxi), under the name of Denticula staurophora. Soon afterwards, two or three other evidently nearly allied diatoms were observed by Professor WalkerArnott and myself in Californian guano; and my attention having been thus attracted to these remarkable forms, I lost no subsequent opportunity of searching for them, both in guano preparations and recent gatherings. Some I have detected in a gathering obtained by washing small algæ picked up on the coast of Jamaica; and several very interesting species occurred in the scrapings of conch shells from Nassau, New Providence, kindly sent to me by Mr. Norman, of Hull. The Caribbean Sea appears to be particularly rich in Diatomacea; and there can be no doubt that this curious little group will be further enlarged when observers shall have been supplied with additional materials from its shores.*

With regard to the affinities of this genus, it seems to be most nearly allied to Odontidium and Denticula; but the presence of vittæ constitutes an important difference. In the place of costæ, also, the species are furnished in almost every instance with conspicuous moniliform striæ. There is, however, in $P$. ornata an approach towards the costæ of Odontidium. The striæ are generally interrupted. The vittæ are composed sometimes of a centrical pair; sometimes with the addition of a solitary one at each extremity of the valve; in one case of a centrical pair, with an indefinite additional number.

* I take the opportunity of recommending that those who are interested in this subject, and have friends in the West Indies, should eudeavour to prerail upon them to collect the smaller sea-weeds, especially such as are cast ashore in quiet bays and creeks. It should be explained to them that the ubject is not the sea-wecds themselves, but the diatoms to be obtained from them, and that those sea-weeds are to be preferred which are covered

VOL. VII. 


\section{Plagiogramma, Grev.}

Frustules quadrangular, direct, two or more united into a filament; valves linear or elliptical ; striæ moniliform ; vittæ two or more, pervious, parallel with the striæ.

Section I.-Vittæ 2, centrical.

1. P. gregorianum, Grev.-Valve elliptical, obtuse ; striæ pervious, 18 in $001^{\prime \prime}$; frustule in front view somewhat dilated in the middle ; length "0014" to $0030 . "$ (Pl. X, figs. 1, 2.)

Denticula staurophora, Greg., 'Trans. Roy. Soc. Ed.,' vol. xxi, p. 496, pl. x, fig. 37 .

Dredged in Loch Fine, by Dr. Gregory. Lamlash Bay, Island of Arran.

This was justly regarded by the late Professor Gregory as a very curious little diatom, nothing similar to it having been previously noticed. As far as I have had an opportunity of examining the side views of the different species, this is the only one which possesses pervious striæ. It is scarcely necessary to remark that, as the centrical vitta which Dr. Gregory regarded as a stauros, are characteristic of all the species, I have been under the necessity of changing the specific name.

2. P. jamaicense, n. sp., Grev.-Valve . . . . ? frustule in front view with the sides straight; length '0024" ; strix continued almost quite up to the angle, 16 in $001^{\prime \prime}$. (Fig. 3.)

Jamaica, in washings of algæ.

As I have not succeeded in obtaining a side view of the frustule, I am unable to give a satisfactory definition of this species. The vittæ, however, are only centrical, and it is certainly distinct from the preceding. The striæ can scarcely be termed strictly moniliform, but rather moniliform costate. I have another form belonging to this section, also from Jamaica, the frustules of which are ${ }^{\circ} 0020^{\prime \prime}$ in length, and the band of strix considerably narrower; the strix themselves 21 in $001^{\prime \prime}$. It may be a different species, but having only seen the front view, I dare not venture to introduce it as such.

3. P.? tessellatum, n. sp., Grev.-Valve narrow-elliptical;

with parasites and entangled with zoophytes, forming what the mere col. lector of algæ would call unsightiy tufts. They must on no accourt be washed, but dried in the rough, just as picked up, and then packed in coarse paper. Small parcels of this kind (a few ounces in weight), from the coasts of the different islands (and from different localities of the same island), could not fail to produce objects of the highest interest to the diatomist. 
striæ interrupted, composed of large subquadrate granules, 8 in $\cdot 001^{\prime \prime}$; length of frustule $0040^{\prime \prime}$. (Fig. 7.)

In Californian guano.

A single example of this most remarkable diatom is all that I have seen; and I introduce it with considerable hesitation, for I am by no means satisfied that it belongs to the present genus.

Section II. - Vittæ 2, centrical, and one at each end of the valve.

4. P. pulchellum, n. sp., Grev.-Valve linear-elliptical, obtuse ; striæ interrupted, robust, conspicuously moniliform, 11 in $.001^{\prime \prime}$; length of frustule $0025^{\prime \prime}$ to $0057^{\prime \prime}$. (Figs. $4-6$.

In Californian guano; Jamaica, in washings of algæ; Nassau, New Providence, in scrapings of conch shells.

Of this fine species I have seen as many as five frustules united in a chain, but this is extremely rare; for their coherence in the whole genus seems to be very slight. The terminal vittæ are rather distant from the extremities of the valve, and two or three faint and short strix are seen on the side of the vitta next the apex. The striæ are very strong, and conspicuously moniliform. It will be perceived how greatly this species varies with regard to size; but I cannot detect any real difference between the large frustule represented at fig. 6 and the smaller ones forming the chain at fig. 5. There is another form, of which I have only seen the front view, which differs in the striæ being shorter and slightly more numerous (13 in $\left.\cdot 001^{\prime \prime}\right)$. It occurs in Californian guano and in the West Indies.

5. P. validum, n. sp., Grev.-Valve linear, slightly dilated in the middle, rounded at the ends; striæ interrupted, conspicuously moniliform, 12 in $.001^{\prime \prime}$; length of frustule $.0055^{\prime \prime}$, breadth $0007^{\prime \prime}$. (Fig. 8.)

In Californian guano.

As in the preceding species, I have only seen the side view of this diatom, the character of which is abundantly distinct. The valve maintains its breadth to the extremities.

6. P. ornatum, n. sp., Grev.-Valve ...? striæ in front view of frustule broad, moniliform-costate, 8 or 9 in $001^{\prime \prime}$; connecting membrane with longitudinal rows of dots 15 in $\cdot 001^{\prime \prime}$; length of frustule $0052^{\prime \prime}$. (Fig. 9.)

In Californian guano. 
An exquisitely beautiful object, first pointed out to me by my friend Professor Walker-Arnott. I have not seen the side view; the specific character must consequently remain for the present imperfect. The front view, however, is amply sufficient to separate it from any of the species described in this paper. The striæ are very peculiar, broad, and appearing almost like flat plates to the eye; indeed, at first sight, they might be taken for costa, but they are in reality composed of two or three pieces, two only being often visible. Two abbreviated striæ are situated between the terminal vittæ and the angle of the frustule, the last one being a mere spherical granule. What importance may be attached to the beautiful rows of dots, analogous to those which occur in the connecting membrane of some Biddulphia, I am quite unable to say. As they are not present in any of the other species where $I$ have been able to examine the front view, it is reasonable to conclude that they are characteristic of the present form. It can scarcely be assumed that they have any connexion with the strix, as they do not correspond numerically. The terminal vittre in this species are liable to be overlooked in a hasty examination, but they come out quite distinctly with careful adjustment.

7. P. inaquale, n. sp., Grev.-Valve ...? terminal vittæ in front view longer than the centrical ones, and inflected at the apices ; length '0014" to $0016^{\prime \prime}$; striæ moniliform, 16 in -001". (Fig. 10.)

Jamaica, in washings of algæ; Nassau, New Providence, in scrapings of conch shells.

It is fortunate that although, as in several of the preced. ing species, the side view is unknown, the front view should possess such well-marked features. At the first glance the eye is struck with the arrangement of the striæ into, as it were, two distinct groups, caused by the centrical and terminal vittæ being somewhat approximated, and the intervals between them being filled up with the striæ. The inflected apices of the terminal vittæ, and the blank space between the centrical vittæ, contribute to produce this effect. Another remarkable peculiarity is caused by the unequal length of the vittæ; the terminal ones are the longest, their points being inflected inwards; so that the ends of the striæ form an oblique line, descending from the points of the terminal to those of the centrical vittæ. Then, again, the boundary line of the connecting membrane follows on each side the direction of the outline formed by the ends of the strix, and the result is more or less of a rhomboidal figure, of little 
value in the diagnosis, but adding to the singular aspect of the frustule. It seems to be very rare in both stations.

8. P. pygmæum, n. sp., Grev.-Minute; valve narrow-oblong; length $0012^{\prime \prime}$; strix moniliform, 21 in $001^{\prime \prime}$. (Fig. 11.)

Nassau, New Providence, in scrapings of conch shells.

This diatom is distinguished among its congeners for its minute size, its shape, and the small number of striæ; for although they are, in the relative proportion assigned above, there are, in fact, but few in the entire frustule. The valve is not unlike the lower valves of some small Achnanthes, but the decided terminal vittæ serve at once to indicate other affinities.

9. P. obesum, n. sp., Grev.-Minute; valve broadly dilated in the middle, the ends rounded; length '0022", breadth $\cdot 0009^{\prime \prime}$; striæ 11 in $\cdot 001^{\prime \prime}$. (Figs. 12, 13.)

In scrapings of conch shells, Nassau, New Providence.

The intlated appearance of the valve and the small number of striæ render this a well-marked species.

10. $P$. lyratum, n. sp., Grev.-Valve contracted in the middle, then dilated and narrowly lyriform, linear and rounded at the extremities; length $\cdot 0042^{\prime \prime}$; striæ 18 in $\cdot 001^{\prime \prime}$. (Fig. 14.)

In scrapings of conch shells, Nassau, New Providence.

The variety of contour exhibited in the valve of this and the preceding species is a striking illustration of the necessity of obtaining a side view of the frustule in order to make up a complete character, although a sufficient provisional character may sometimes be furnished by the front view. The present diatom, the most beautiful and remarkable of its genus, seems very rare, as I have only met with one example.

Section III.-Number of vittæ between the two centrical ones and the ends of the valve indefinite.

11. P. californicum, n. sp., Grev.-Valve linear, rounded at the ends; vittæ between the centre and apices $3-5$; length $\cdot 0030^{\prime \prime}$ to $\cdot 0038^{\prime \prime}$; striæ 18 in $001^{\prime \prime}$. (Figs. 15-17.)

In Californian guano.

The only species which has come under my notice belonging to this section. 